\title{
The onward march of European public health
}

Analysis of public health problems at a European level (compared with at the nation state level) has been carried out in a serious and systematic manner only in recent decades, and any attempt to prescribe solutions to these problems at a supranational level is even more recent. This is in some ways surprising, as comparatively few of the major determinants of health can be controlled effectively at the nation state level in today's world. Many health determinants are influenced by the effects of globalisation of the world economy, but others (for example, those relating to agriculture and food production, and to environmental control, etc) may be subject to control on the basis of legislation and other measures determined at a European level.

Public health programmes at a European level were first planned and implemented during the 1980s. At that time this was on the basis of voluntary collaboration between governments of member states of the European Community, as there was then no legal basis for public health activities within the Treaty of Rome. The ministers of health of the member states, meeting as the Health Council of the Community, asked the European Commission to service and to administer this voluntary collaboration on public health programmes. Accordingly, a public health unit was set up within Directorate General (DG) V, which already had responsibility for health and safety at work $(\mathrm{H}$ Stein, personal communication, 1995). By the early 1990s a number of these European programmes were operating, and it was therefore not very surprising that a public health competence was included for the first time within the Treaty of Rome, as amended at the Maastricht InterGovernmental Conference (IGC), in 1992. ${ }^{1}$

Such was the origin of Article 129, the new public health article. ${ }^{1}$ However, if the expectation of health ministers was that this would merely provide a legal basis for continuing voluntary collaboration on some public health programmes, similar to that which had preceded the Maastricht IGC, they were to receive more than they had bargained for. Although referring to support for the actions of member states, the wording of the article places it clearly within the "first pillar" of the Treaty. This prescribes a system according to which the Commission initiates policy and legislation, which then has to be approved both by European Parliament and by the Health Council (which consists of the health ministers of all the member states, who take decisions on the basis of a qualified majority system of voting). In addition, there was a further significant clause written into Article 129: this requires the institutions of the European Union (EU) to consider the implications for protection of the public health of all EU legislation and programmes.

This new article appeared to offer new and exciting possibilities to the European Commission. Most observers at the time expected the Commission to try to define a first European public health strategy. However, instead it began to tackle its new responsibilities with great timidity. It issued, rather than any strategy, a "framework document". ${ }^{2}$ This described a number of ad hoc programmes that the Commission intended to introduce over the subsequent five years. Some of these are now currently operating ${ }^{3-6}$; others are at present the subjects of relevant legislation, which is proceeding through the Parliament and the Council..$^{7-9}$ A "health monitoring" programme ${ }^{10}$ is also planned - this should provide a public health common data set at EU level. As a response to the health protection clause in Article 129, reports have been issued ${ }^{11}$ that pur- port to demonstrate how seriously all parts of the European Commission view their health protection responsibilities. However, these have been so far little more than public relations exercises by the Commission, and there have been no serious health impact assessments of its policies carried out either by the Commission itself, or on its behalf.

As Article 129 was implemented as recently as November 1993, there was until 1996 no expectation that it would be changed as soon as the next IGC, which was the one that ended at Amsterdam in June 1997. Then came the bovine spongiform encephalitis/Creutzfeldt-Jacob disease (BSE/ CJD) crisis. The European Parliament approved a report $t^{13}$ that was exceedingly critical, both of the UK government of the day, and of the European Commission itself. The Parliament even considered dismissing the entire Commission. Jacques Santer, President of the Commission, spoke to the Parliament in a voice of uncharacteristic contrition. $\mathrm{He}$ even promised that, in future, public health would be "at the forefront of the development of Europe". The Commission changed a number of its own administrative arrangements, including the setting up in DG XXIV of a new directorate for "consumer health protection". This new directorate is already working to strengthen the arrangements of the EU for assurance of food safety and healthy nutrition. However, the Commission also joined the Parliament in calling for a strengthened public health article in the Treaty of Rome.

Article 129 specifically excludes from EU competence any activities designed to harmonise the public health protection laws of the member states. Drawing a conclusion (based on its experience of BSE/CJD, and the UK's perceived failure to control this epidemic) that these laws seemed not to be adequate, the Commission proposed, for the next (Amsterdam) IGC, its own revised public health Article. This would have reversed the current situation, therefore permitting harmonisation of public health legislation. The Commission's proposal was watered down considerably during the final stages of the IGC, but the final text of the new draft Treaty, ${ }^{14}$ published in October 1997, includes a new public health Article 152, which would permit harmonisation of laws in certain limited specified areas. The most significant of these includes everything pertaining to the human public health protection implications of animal and plant health, in the context of food production. Another relates to blood, blood products, and to other human tissues. The new article also includes a much strengthened public health protection statement, requiring the EU institutions to consider the health implications of all EU programmes and legislation, of all kinds, both at policy development and implementation stages. The new treaty at present awaits ratification by all member states before it can be implemented: so far the ratification process is proceeding satisfactorily.

The present situation can therefore be summed up as one containing many opportunities, but also some challenges. Public health is at present high on the EU political agenda, after the BSE/CJD debacle. A new Treaty Article, with stronger powers, is likely to be implemented soon. The first public health programmes (introduced under Article 129) will all soon be operating, and the Commission, aware that it needs to determine what should follow these programmes, has recently published a new "paving" document on the development of public health policy. This indicates high priority in future to the improvement of public health information systems, and to 
the development of a rapid response capability to new health threats. The existing public health funded programmes would be replaced by one generic public health and health promotion programme. Meanwhile, the Commission is also giving serious consideration to the matter of how public health should in future be organised within its own structures. The current Commission will soon be replaced by a new one, which will include new Commissioners; is it possible that, in the next Commission, there might be a new public health DG?

In the meantime, the current opportunities and challenges need to be addressed by public health professionals, and by their organisations. Now is the time to demonstrate to the Commission in clear terms the nature of health need across Europe, and the way this might be tackled in terms of a genuine strategy for European public health. Public health is now becoming properly organised across all EU member states. The European Public Health Association (EUPHA) ${ }^{15}$ represents academics and public health professionals, and the European Public Health Alliance (EPHA) ${ }^{16}$ brings together many health oriented NGOs and other organisations. These organisations should now demonstrate their potential for leadership of the public health movement at EU level, possibly by establishing jointly a European public health platform, to which other public health organisations operating across the EU could also affiliate. The Commission and the other EU institutions are clearly in need of professional public health advice, and such a public health platform would be ideally placed to provide this.

CHRISTOPHER A BIRT

University of Birmingham Collaboration for Public Health in Europe

1 Article 129. Treaty on European Union, as signed in Maastricht. Luxembourg: Office for Official Publications of the European Communities, 1992.
2 Commission communication on the framework for action in the field of public health, COM(93)559 final. Brussels: Commission of the European Communities, 1993

3 Action plan 1995-1999 to combat cancer within the framework for action in the field of public health, COM(94) 83 final. Brussels: Commission of the European Communities, 1994.

4 Programme of Community action on health promotion, information, education and training within the framework for action in the field of public health, COM(94) 202 final. Brussels: Commission of the European Communities, 1994.

5 Programme of Community action on the prevention of drug dependence within the framework for action in the field of public health (1995-2000), COM(94) 223 final. Brussels: Commission of the European Communities, 1994.

6 Programme of Community action on the prevention of AIDS and certain other communicable diseases within the framework for action in the field of public health, $\operatorname{COM}(94) 413$ final. Brussels: Commission of the European Communities, 1994

7 Programme of Community Action from 1999 to 2003 on injury prevention in the context of the framework for action in the field of public health, COM(97) 178 final. Brussels: Commission of the European Communities, 1997.

8 Programme of Community action 1999-2003 on rare diseases in the context of the framework for action in the field of public health, COM(97) 225 final. Brussels: Commission of the European Communities, Communication from the Commission concerning a programme of Community action, 1997.

9 Communication from the Commission concerning a programme of Community action on pollution-related diseases in the context of the framework for action in the field of public health, COM(97) 266 final. Brussels: Commission of the European Communities, 1997.

10 Programme of Community action on health monitoring in the context of the framework for action in the field of public health, COM(95) 449 final. Brussels: Commission of the European Communities, 1995.

11 Report from the Commission to the Council, the European Parliament and the Economic and Social Committee on the integration of health protection requirements in Community policies, COM(95) 196 final. Brussels: Commission of the European Communities, 1995.

12 Second report from the Commission to the Council, the European Parliament, the Economic and Social Committee and the Committee of the Regions on the integration of health protection requirements in Community policies (1995), COM(96) 407 final. Brussels: Commission of the European Communities, 1996.

13 Ortega MM. Report on alleged contraventions or maladministration in the implementation of Community law in relation to BSE, without prejudice to the jurisdiction of the Community and national courts, Part A. Brussels: European Parliament session documents, 1997

14 Consolidated version of the Treaty establishing the European Community, CONF 4005/97 ADD 2. Brussels: Conference of the Representatives of the Governments of the Member States, 1997.

15 Svensson P-G, Stephenson P. A note from the editorial office. Eur f Public Health 1993;3:1.

16 Roberts LS. Health care policies and Europe. Oxford: ButterworthHeinemann, 1996 